\title{
ANALISIS KUALITAS PELAYANAN TERHADAP KEPUASAN MASYARAKAT DI PUSKESMAS KUBUTAMBAHAN II DESA TAMBLANG KECAMATAN KUBUTAMBAHAN KABUPATEN BULELENG BALI TAHUN 2020
}

\author{
Luh Made Sri Lestari ${ }^{1}$
}

\begin{abstract}
'Program Pascasarjana Universitas Terbuka drgsrilestari@gmail.com

This study aimed to determine the effect of quality, which includes tangible, reliability, responsiveness, assurance, and empathy, on patient satisfaction and the quality dimensions that most dominantly affect patient satisfaction at Community Health Center (Puskesmas) Kubutambahan II. This research was conducted in communities where Puskesmas Kubutambahan II is responsible for in 2020 with a sample of 100

Received : 05 May 2021 Revised : 15 June 2021 Accepted : 17 June 2021 Published : 21 June 2021 respondents. The independent variables are responsiveness, reliability, empathy, tangible, and assurance, while the dependent variable is community satisfaction in the working area of Puskesmas Kubutambahan II. Variable measurement was done by using a valid and reliable service quality questionnaire and a satisfaction questionnaire. Data were analyzed using descriptive statistical analysis methods followed by the chi-square technique for bivariate analysis and logistic regression for multivariate analysis. The analysis found that 55\% of the people reported that they were satisfied with the quality of services provided by the Puskesmas. The results of the analysis reported that the dominant variable associated with satisfaction was good empathy (AOR: 5.2, 95\% CI 1.7-15.5), good responsiveness (AOR: 3.3, 95\% CI 1.O- 10.3), and good reliability (AOR: 4.4, 95\% CI 1.1-17.5). The community's dissatisfaction of 45\% was multivariate related to sufficient tangibility (AOR: 0.04 , 95\% CI O.005-0.3), sufficient empathy (AOR: 22.2, 95\% CI 4.1-118.7), sufficient reliability (AOR: 5.2, 95\% CI 1.2-23.2), sufficient responsiveness (AOR: 5.3 95\% CI 1.4-19.9), and sufficient assurance (AOR 2,04,95\% CI $0,4-9,5)$. The conclusion is that the most dominant variables associated with increasing community satisfaction with health services are responsiveness, reliability, and empathy. Meanwhile, the variables that were not statistically related to satisfaction were tangible, and assurance
\end{abstract}

Keywords: community health care; quality; satisfaction

\section{ABSTRAK}

Tujuan penelitian ini adalah untuk mengetahui pengaruh kualitas yang meliputi tangible, reliability, responsiveness, assurance, dan empathy terhadap kepuasan pasien dan dimensi kualitas yang paling dominan mempengaruhi kepuasan pasien di Puskesmas Kubutambahan II. Penelitian ini dilakukan pada masyarakat di wilayah kerja Puskesmas Kubutambahan II tahun 2020 dengan sampel sebanyak 100 responden. Variabel independen adalah responsiveness, reliability, empathy, tangible, and assurance, sedangkan variabel dependennya adalah kepuasan masyarakat di wilayah kerja Puskesmas Kubutambahan II. Pengukuran variabel dilakukan dengan menggunakan kuesioner kualitas pelayanan dan kuesioner kepuasan yang valid dan reliabel. Analisis data dilakukan dengan menggunakan metode analisis statistik deskriptif dilanjutkan dengan analisis menggunakan teknik chi square untuk analisis bivariat dan regresi logistik untuk analisis multivariat. Analisis menemukan bahwa secara umum, 55\% masyarakat melaporkan bahwa mereka puas dengan kualitas layanan yang diberikan oleh puskesmas. Hasil analisis menunjukkan bahwa variabel dominan yang berhubungan dengan kepuasan adalah empati yang baik (AOR: 5.2, 95\% CI 1.7-15.5), daya tanggap yang baik (AOR: 3.3, 95\% CI 1.0- 10.3) dan kehandalan yang baik (AOR: 4.4, 95\% CI 1,1-17,5). Ketidakpuasan masyarakat sebesar $45 \%$ bersifat multivariat terkait dengan cukup bukti fisik/tangible (AOR: 0,04, 95\% CI 0,005-0,3), cukup empati (AOR: 22,2, 95\% CI 4,1-118,7), cukup kehandalan (AOR: 5,2, 95\% CI 1.2-23.2), daya tanggap cukup (AOR: 5.3 95\% CI 1.4-19.9), dan jaminan cukup (AOR 2,04,95\% CI 0,4-9,5). Kesimpulannya variabel yang paling dominan berhubungan dengan peningkatan kepuasan masyarakat terhadap pelayanan kesehatan adalah daya tanggap, kehandalan dan empati. Sedangkan variabel yang secara statistik tidak berhubungan dengan kepuasan adalah tangible dan assurance

Kata Kunci: puskesmas; kualitas; kepercayaan 


\section{PENDAHULUAN}

Pembangunan kesehatan sebuah bangsa bertujuan untuk meningkatkan kesadaran masyarakat, kemauan dan kemampuan hidup sehat bagi setiap orang demi terwujudnya kesehatan yang optimal. Puskesmas dan Jaminan Kesehatan Nasional adalah sebuah halyang saling berkaitan dan tidak bisa dipisahkan. Sehingga akan sangat mudah berdampak pada pelayanan kesehatan yang dirasa buruk atau baik.

Kualitas pelayanan yang didapatkan pasien pada fasilitas pelayanan kesehatan menjadi salah satu faktor penting dalam pemanfaatan pelayanan kesehatan. Pelayanan yang baik tidak terbatas pada kesembuhan sebuah penyakit, tetapi terdapat hal lain yang mendukung lagi pelaksanaan pelayanan kesehatan yang berkualitas yaitu komunikasi, informasi, sopan santun, tepat waktu, tanggap serta tersedianya sarana dan prasarana yang baik di Puskesmas (Fenny, Enemark, Asante, \& Hansen, 2014). Kualitas dalam sebuah pelayanan secara langsung dapat memunculkan sebuah rasa puas atau tidaknya klien atau pasien. Kepuasan berarti sebuah respon seorang terhadap ketidaksesuaian yang diinginkan dengan yang terjadi sebenarnya (Kuntoro \& Istiono, 2017).

Sejak 1 Januari 2014, Puskesmas Kubutambahan II mulai melaksanakan program pemerintah yaitu program Jaminan Kesehatan Nasional (JKN) sehingga terdapat peningkatan kunjungan pasien berobat ke Puskesmas Kubutambahan II, namun dari hasil studi pendahuluan yang dilakukan di Puskesmas Kubutambahan II dari 10 pasien yang dilakukan wawancara 6 pasien (60\%) yang mengatakan masih ada keluhan tentang pelayanan yang diberikan di Puskesmas Kubutambahan II, hal ini memberikan gambaran bahwa masih ada pasien yang belum puas terhadap pelayanan yang diberikan karena berbagai faktor seperti kesediaan obat, sarana prasarana, keramahan pegawai, komunikasi, waktu antre lama serta sarana pengaduan yang tidakjelas dan sebaliknya 4 pasien (40\%) mengatakan sudah puas dengan pelayanan kesehatan yang diberikan.

Pada kondisi-kondisi gawat darurat, sering kali pasien mengeluhkan kurang tersedianya fasilitas ruangan gawat darurat yang representatif untuk keluarga pasien maupun pasien, dalam artian sistem pemilahan pasien sesuai standar. Hal inilah yang menyebabkan peneliti untuk melakukan penelitian terkait dengan kualitas pelayanan yang diberikan di Puskesmas Kubutambahan II terhadap kepuasan pasien atau masyarakat di era Jaminan Kesehatan Nasional ini. Penelitian sebelumnya (Pundenswari, 2017) menunjukkan bahwa kualitas layanan kesehatan sangat berpengaruh positif pada kepuasan masyarakat. Pengaruh kualitas pelayanan yaitu pada kepuasan masyarakat khususnya masyarakat pengguna pelayanan kesehatan. Kondisi ini didukung oleh hasil penelitian (Andriani, 2017) yang menemukan bahwa terdapat hubungan mutu pelayanan kesehatan dengan kepuasan pasien di ruangan Poli Umum Puskesmas Tigo Baleh Bukittinggi. Sejalan dengan kedua penelitian di atas, hasil lain yang juga mendukung yaitu hasil penelitian yang dilakukan (Kuntoro \& Istiono, 2017) yang menemukan bahwa faktor kualitas pelayanan dilihat dari tangibles, reliability, responsiveness, assurance, emphaty, mempengaruhi tingkat kepuasan pasien yang menjalani rawatjalan di Puskesmas Kretek Bantul Yogyakarta. Pada penelitian ini ditemukan hasil bahwa mayoritas pasien puas terhadap dimensi tangibles di Puskesmas, Pada dimensi tangibles, sebagian besar pasien percaya dan yakin pada kehandalan dan keakuratan yang diberikan petugas pelayanan kesehatan dengan cepat dan tepat, ketanggapan yang diberikan petugas layanan kesehatan dalam memberikan informasi serta ketanggapan petugas kesehatan dalam menyelesaikan permasalahan yang dihadapi oleh pasien sangat dirasakan pasien pada dimensi tangibles. Pada dimensi assurance, petugas mendapat sebagian besar kepercayaan pasien dalam hal memberikan jaminan pada kualitas pelayanan kesehatan. Dimensi terakhir yaitu emphaty, menjelaskan bahwa dalam penelitian mayoritas petugas pelayanan kesehatan mendapatkan penilaiaan ramah, sopan, serta selalu memberikan salam serta kesempatan diskusi dengan pasien kesehatan terkait kondisi kesehatannya. Hal ini akan menimbulkan rasa puas pada pasien karena sikap empati yang ditunjukkan oleh petugas.

\section{METODE}

Metode yang digunakan dalam penelitian ini yaitu metode kuantitatif dengan desain penelitian survei pendekatan secara cross 
Analisis Kualitas Pelayanan terhadap Kepuasan Masyarakat di Puskesmas Kubutambahan II Desa Tamblang Kecamatan Kubutambahan Kabupaten Buleleng Bali Tahun 2020

Luh Made Sri Lestari

sectional yang diambil dalam satu waktu. Variabel independen kualitas pelayanan, sedangkan variabel dependen adalah kepuasan masyarakat di wilayah kerja Puskesmas Kubutambahan II. Populasi penelitian yaitu pasien/masyarakat di wilayah kerja Puskesmas Kubutambahan II Tahun 2020. Penarikan sampel dilakukan dengan menggunakan teknik probability random sampling melalui cluster random sampling didapatkan sampel sebanyak 100 responden. Pengukuran variabel dilakukan dengan menggunakan kuesioner kualitas pelayanan dan kuesioner kepuasan yang sudah valid dan reliable. Analisa data dilakukan dengan menggunakan metode analisis statistik deskriptif. Analisis yang digunakan yaitu univariat dan bivariat dengan uji chi square. Analisis ini untuk melihat variabel yang dapat masuk ke dalam analisis multivariat dengan batas nilai $\mathrm{p} \geq 0.2$. Analisa data menggunakan software SPSS. Penelitian dilakukan pada pasien/masyarakat di wilayah kerja Puskesmas Kubutambahan II yang berkunjung tiap hari Senin sampai Sabtu dari pukul 08.00-12.00 WITA kecuali hari Jumat sampai jam 11.00 WITA. Dimulai sejak tanggal 6 September sampai dengan 10 Oktober tahun 2020.

\section{HASIL DAN PEMbahasan}

\section{Hasil}

\section{Karakteristik Responden}

Rata-rata umur responden yaitu berada pada usia 36 tahun dengan standar deviasi $\pm 10,9$. Kemudian sebagian besar responden berjenis kelamin perempuan yang mengisi kuesioner dan berkunjung ke pelayanan kesehatan yaitu sebanyak $67 \%$. Sebagian besar sebaran tempat tinggal responden yang dilaporkan dalam kuesioner adalah Desa Tamblang yaitu sebanyak 21\%. Hasil analisis univariat terkait dengan pendidikan responden menunjukkan bahwa sebagian besar responden berpendidikan terakhir Sekolah Menengah Atas (SMA) sebanyak 39\%. Hasil penelitian ini menemukan bahwa sebagian besar responden memiliki pekerjaan sebagai petani sebanyak 24\%. Kemudian sebagian besar responden berjenis kelamin perempuan yang bekerja sebagai IRT (Ibu Rumah Tangga) yaitu sebanyak 22\%.
Hasil analisis univariat terkait dengan dimensi responsiveness yang terkait dengan pelayanan petugas yang cepat dan tepat dalam melayani. Sebagian besar melaporkan bahwa petugas cepat sesuai dengan porsinya (68\%). Kemudian petugas tepat dan sesuai dalam memberikan pelayanan (56\%). Hasil analisis pada dimensi reliability dengan jumlah poin pertanyaan sebanyak empat pertanyaan menemukan bahwa pelayanan dokter sangat sesuai saat memberitahu diagnosa (70\%). Kemudian pelayanan yang diberikan sesuai (67\%), sesuai dengan jadwal (50\%) dan sesuai dalam pelaksanaan kedisiplinan (54\%). Hasil analisis univariat dimensi emphaty bahwa petugas kesehatan sesuai dalam hal menyapa dengan ramah (68\%) dan sesuai dalam hal melayani dengan kepedulian (58\%). Hasil analisis univariat pada dimensi assurance ditemukan bahwa petugas kesehatan mengobati sesuai dan tepat dengan diagnosa (66\%), kemudian obat yang diberikan sesuai untuk mempercepat penyembuhan (70\%) dan jaminan kesehatan yang digunakan juga seseuai dengan pelayanan yang diberikan (59\%).

Hasil analisis univariat pada dimensi tangible melaporkan bahwa fasilitas fisik Puskesmas Kubutambahan II sesuai baik (72\%) kemudian kesesuaian sarana lengkap (73\%) kesesuaian lingkungan yang bersih (69\%), kesesuaian dalam hal kenyamanan (63\%). Selain itu petugas kesehatan juga dilaporkan sesuai dalam penggunaan seragam kerja (60\%), petugas juga sesuai dalam penggunaan tanda pengenal yaitu sebesar 66\%. Hasil analisis univariat terkait dengan kepuasan, sebagian besar responden melaporkan puas akan pelayanan yang diberikan yaitu sebesar $55 \%$.

\section{Analisis Bivariat Variabel Independen dan Dependen}

Hasil analisis bivariat menemukan bahwa dimensi responsiveness yang baik sebanyak $63,6 \%$ puas dalam pelayanan kesehatan dan $36,4 \%$ tidak puas terhadap pelayanan kesehatan. Secara analisis bivariat dimensi ini signifikan secara statistik dilihat dari nilai $\mathrm{p}<0,05$. Hasil analisis bivariat melaporkan bahwa dimensi reliability yang baik sebanyak $69,1 \%$ mengalami kepuasan dalam pelayanan kesehatan yang diterima ketika berkunjung ke Puskesmas 
dan sebanyak 30,9\% tidak puas. Hasil ini juga signifikan secara statistik dibuktikan dengan nilai $\mathrm{p}<0,05$. Hasil analisis bivariat dimensi empathy dengan kepuasan dilaporkan bahwa responden yang melaporkan baik dari segi empathy sebanyak $67,3 \%$ puas terhadap pelayanan yang diterima dan hasil ini signifikan secara statistik dengan nilai $\mathrm{p}<0,05$.

Hasil analisis bivariat menemukan bahwa responden yang melaporkan bahwa dimensi assurance baik sebanyak 60\% puas terhadap pelayanan kesehatan sedangkan 40\% tidak puas akan pelayanan kesehatan yang diterima. Hasil ini signifikan secara statistik dengan nilai p <0,05. Hasil analisis bivariat menemukan bahwa dimensi kualitas pelayanan tangible baik sebanyak $41,8 \%$ puas terhadap pelayanan dan sisanya $58,2 \%$ menyatakan tidak puas terhadap pelayanan yang diberikan. Hasil ini secara statistik atau analisis bivariat tidak signifikan terbukti bahwa nilai $\mathrm{p}>0,05$.

\section{Analisis Multivariat Faktor Yang Dominan Terhadap Kepuasan Pelayanan}

Tabel 1. Variabel Yang Dominan Berhubungan Dengan Kepuasan Masyarakat

\begin{tabular}{lrrrr}
\hline \multirow{2}{*}{ Variabel } & \multirow{2}{*}{ AOR } & Nilai & \multicolumn{2}{c}{$95 \%$ CI } \\
\cline { 3 - 5 } & & $\mathrm{p}$ & Lower & Upper \\
\hline $\begin{array}{l}\text { Responsiveness } \\
\text { yang baik }\end{array}$ & 3,3 & 0,043 & 1,0 & 10,3 \\
$\begin{array}{l}\text { Reliability yang } \\
\text { baik }\end{array}$ & 4,4 & 0,038 & 1,1 & 17,5 \\
$\begin{array}{l}\text { Empathy yang } \\
\text { baik }\end{array}$ & 5,2 & 0,003 & 1,7 & 15,5 \\
$\begin{array}{l}\text { Assurance yang } \\
\text { baik }\end{array}$ & 0,7 & 0,73 & 0,2 & 3,3 \\
\hline
\end{tabular}

Hasil analisis multivariat yang ditemukan bahwa variabel kualitas pelayanan berupa responsiveness yang baik 3.3 kali dapat meningkatkan kepuasan masyarakat saat mendapatkan pelayanan di puskesmas (AOR: 3,3, 95\% CI 1,0-10,3). Hasil ini signifikan secara statistik yang dibuktikan dengan hasil nilai $\mathrm{p}$ $<0,05$ dan 95\% CI tidak melewati angka nol. Kemudian reliability yang baik dari dimensi kualitas 4.4 kali beresiko dapat meningkatkan kepuasan masyarakat saat mendapatkan pelayanan di puskesmas (AOR: 4,4, 95\% CI 1,1-
17,5). Hasil ini juga signifikan secara statistik yang dilihat dari nilai $\mathrm{p}<0,005$ dan $95 \% \mathrm{CI}$.

Variabel selanjutnya adalah empathy yang baik dalam memberikan pelayanan 5.2 kali berisiko dapat meningkatkan kepuasan masyarakat dalam memperoleh pelayanan kesehatan (AOR: 5,2, 95\% CI 1,7-15,5). Hasil ini signifikan secara statistik dibuktikan dengan nilai $\mathrm{p}<0,05$ dan 95\% CI tidak melewati angka nol. Sedangkan dimensi kualitas pelayanan dari segi assurance secara statistik tidak signifikan dibuktikan dengan nilai $\mathrm{p}>0,05$.

\section{Pembahasan}

\section{Hubungan Tangible Dengan Kepuasan}

Hasil penelitian ini menemukan sebagian besar responden melaporkan bahwa puskesmas Kubutambahan II cukup tangible yaitu sebanyak $64 \%$. Kemudian hasil analisis bivatriate menemukan bahwa $41,8 \%$ pasien yang puas dengan pelayanan melaporkan tangible dalam keadaan baik. Namun secara analisis bivariat tidak ditemukan hubungan yang signifikan secara statistik antara kepuasan dengan tangible atau bukti fisik atau penampakan Puskesmas secara nyata. Hasil penelitian sebelumnya yang sejalan menemukan bahwa sebagian besar responden melaporkan cukup dalam hal dimensi kenyataan kualitas pelayanan kesehatan yang diterima (Syaifulloh, 2011).

\section{Hubungan Realibility Terhadap Kepuasan Pasien}

Hasil analisis secara bivariat bahwa sebanyak $63,6 \%$ responden yang puas menyampaikan bahwa reliability yang ditunjukkan oleh puskesmas baik sehingga dapat meningkatkan kepuasan pasien terhadap pelayanan yang diberikan. Hasil penelitian ini sejalan dengan penelitian sebelumnya yang menemukan bahwa variabel dimensi kehandalan atau reliability berpengaruh terhadap kepuasan pasien dimana setiap perubahan satu poin disebabkan karena kehandalan dalam pelayanan maka dapat secara positif meningkatkan kepuasan pasien terhadap pelayanan kesehatan yang diberikan (Hasnih., Gunawan., 2016). Pelayanan yang diberikan harus selalu baik sehingga pasien akan semakin nyaman dan puas. Jujur juga menjadi poin penting dari 
Analisis Kualitas Pelayanan terhadap Kepuasan Masyarakat di Puskesmas Kubutambahan II Desa Tamblang Kecamatan Kubutambahan Kabupaten Buleleng Bali Tahun 2020

Luh Made Sri Lestari

kehandalan sehingga dengan kejujuran dari petugas kesehatan akan membuat pasien menjadi semakin tahu keadaan pasien saat ini (Tjiptono \& Candra, 2005).

Hubungan Responsiveness Terhadap

Kepuasan Pasien

Responsiveness merupakan salah satu dimensi yang berhubungan secara signifikan dalam meningkatkan kepuasan masyarakat atau kepuasan pelanggan saat memperoleh pelayanan kesehatan di Puskesmas. Dimensi ini merupakan ketepatan petugas kesehatan dalam memberikan pelayanan, waktu pelayanan yang sangat jelas sehingga pasien dapat dengan mudah menentukan dirinya kapan untuk melakukan pemeriksaan. Waktu tunggu untuk medapatkan pelayanan juga tidak terlalu lama sehingga hal ini secara bivariat sangat signifikan mempengaruhi kepuasan pelayanan.

Hasil penelitian sebelumnya juga menemukan hal yang sama bahwa secara bivariate responsiveness atau daya tanggap memiliki hubungan yang signifikan dan secara positif juga meningkatkan kepuasan pelanggan atau masyarakat saat menerima pelayanan (Hasnih., Gunawan., 2016).

\section{Hubungan Dimensi Assurance Dengan Kepuasan Pasien}

Hasil dari analisis pengaruh dimensi assurance terhadap kepuasan pasien Puskesmas Kubutambahan II menunjukkan hasil bahwa berpengaruh secara positif terhadap tingkat kepuasan pasien $\mathrm{p}<$ o.001. Hasil analisa ini menunjukkan jika dimensi assurance semakin meningkat maka tingkat kepuasan pasien terhadap pelayanan kesehatan juga akan meningkat.

Perlunya perhatian penyedia layanan kesehatan terkait kualitas pelayanan kesehatan yaitu pencapaian level yang tinggi pada kepuasan pasien, adalah untuk perkembangan kualitas pelayanan di masa yang akan datang serta sebagai analisis pembanding guna ketahanan terhadap persaingan pada pasar penyedia layanan keseahatan (Al-Nehyadi, Hamda, Abdallah, \& Malik, 2018).

Hasil dari penelitian di atas sesuai dengan penelitian yang dilakukan sebelumnya yang menemukan bahwa dimensi assurance berpengaruh secara langsung terhadap kepuasan pasien $\mathrm{p}<0.001$ dan juga berpengaruh langsung terhadap loyalitas pasien terhadap pelayanan kesehatan $\mathrm{p}<0.001$. Ini mengindikasikan bahwa assurance akan langsung berpengaruh kepada kepuasan pasien yang baik, kemudian setelah pasien merasa puas maka pasien akan mempunyai rasa setia atau loyal secara sendirinya untuk terus memanfaatkan pelayanan yang diberikan oleh pihak penyedia layanan kesehatan (Meesala \& Paul, 2018).

\section{Hubungan Dimensi Empathy Dengan Kepuasan Pasien}

Dimensi yang terakhir dari sebuah kualitas pelayanan yang diberikan adalah empathy. Hasil analisis bivariat menunjukkan bahwa $67,3 \%$ pasien yang puas terhadap pelayanan kesehatan melaporkan bahwa dimensi empati dari petugas kesehatan baik. Hasil ini juga signifikan secara statistik. Hasil penelitian ini sejalan dengan penelitian yang terdahulu dilakukan bahwa dimensi empathy secara langsung berhubungan dengan kepuasan pasien. Empathy juga berpengaruh positif untuk meningkatkan kepuasan (Hasnih., Gunawan., 2016).

\section{Faktor Dimensi Kualitas Pelayanan Yang Paling Dominan Berhubungan Dengan Kepuasan Pasien Di Puskesmas Kubutambahan II}

Pada pengujian regresi logistik, keempat dimensi kualitas pelayanan, reability, responsiveness, assurance, dan empathy secara bersama-sama dimasukkan dalam uji analisis dan hasil dari keempat dimensi tersebut didapatkan hasil bahwa keempat dimensi secara bersama-sama mempunyai pengaruh terhadap kepuasan pasien, dimana dimensi empathy memiliki pengaruh paling dominan dalam memberikan pengaruh kualitas pelayanan terhadap tingkat kepuasan pasien di Puskesmas Kubutambahan II. Dimensi selanjutnya yang berpengaruh terhadap kepuasan pasien diikuti oleh reliability, responsiveness, dan assurance.

Dimensi tangible disini tidak terlalu dominan karena walaupun dengan dimensi tangible yang baik dan sudah disediakan oleh pihak penyedia layanan kesehatan tetapi kembali lagi pasien lebih beorientasi terhadap pelayanan yang diberikan oleh subjek penyedia layanan kesehatan yaitu petugas kesehatan itu sendiri. $\mathrm{Hal}$ 
ini sesuai dengan kondisi yang ada di Puskesmas Kubutambahan II. Meskipun kualitas sarana dan prasana di Puskesmas tidak terlalu baik atau bisa dikatakan standar, tetapi minat dan respon masyarakat sebagai pasien untuk menggunakan fasilitas kesehatan Puskesmas masih tetap tinggi karena dimensi ketanggapan, kehandalan, empati dan jaminan yang diberikan oleh petugas kesehatan Puskesmas Kubutambahan II cukup baik. Kondisi ini tidak berarti bahwa standar untuk kualitas dimensi tangible yang mesti diberikan tidak ditingkatkan. Puskesmas Kubutambahan II perlu meningkatkan kualitasnya untuk mendukung keempat dimensi yang lain. Dari pengamatan peneliti selama melakukan penelitian, ketanggapan, empati, kehandalan dan jaminan yang diberikan petugas kesehatan gigi sudah cepat tanggapan dan sudah jelas dalam memberikan informasi penyakit serta rencana perawatan yang dibutuhkan pasien. Begitu juga rasa empati pasien, petugas kesehatan selalu mengatahui tindakan yang tepat untuk mengatasi masalah kesehatan yang sedang dihadapai oleh pasien. Perlengkapan sarana dan prasana pasien di pelayanan kesehatan yang lengkap atau meningkat, belum tentu akan meningkatkan kepuasan pasien rawat jalan (Supartiningsih, 2017)

Perbedaan kualitas dari setiap dimensi yang berbeda-beda sering kali membuat kekecewaan dari pasien, meskipun petugas kesehatan sudah menerapkan standar operasional prosedur yang baik. Oleh karena itu, kepuasan pasien perlu mendapatkan perhatian karena walaupun sifatnya subyektif, hal ini menentukan preferensi selanjutnya dalam memilih sarana pelayanan kesehatan. Sebagai penyedia jasa yang memberikan berbagai macam pelayanan bagi konsumen, kepuasan pasien adalah tujuan utama yang harus dipenuhi oleh layanan kesehatan. Kepuasan konsumen adalah tingkat perasaan seseorang setelah membandingkan kinerja atau hasil yang dirasakannya dengan harapannya. Jadi, untuk meningkatkan kepuasan pasiennya, khususnya pasien di Puskesmas, peranan dokter, dan perawat baik medis dan non medis sangat menentukan persepsi pasien terhadap pelayanan yang diberikan (Supartiningsih, 2017).

\section{KESIMPULAN}

Dapat ditarik kesimpulan dalam penelitian ini yaitu tidak ada hubungan antara dimensi tangible dengan kepuasan pasien di Puskesmas Kubutambahan II tetapi ada hubungan antara dimensi reliability, responsiveness, assurance, dan empathy dengan kepuasan pasien di Puskesmas Kubutambahan II.

Faktor yang dominan mempengaruhi peningkatan kepuasan pelanggan adalah dimensi responsiveness, reliability, serta empathy. Secara umum sebanyak 55\% masyarakat melaporkan dirinya puas dengan kualitas pelayanan yang diberikan oleh Puskesmas. Implikasi penelitian ini adalah petugas kesehatan secara umum dan secara khusus Kepala Puskesmas dapat meningkatkan dimensi yang dapat meningkatkan kepuasan termasuk dimensi tangible dan assurance agar kualitas pelayanan dan kepuasan masyarakat terus dapat ditingkatkan

Saran untuk peneliti selanjutnya untuk melakukan penelitian lebih lengkap dan terkait dimensi kualitas dan dimensi kepuasan dikembangkan untuk melakukan evaluasi kualitas dan kepuasan dari pelayanan kesehatan yang diberikan kepada masyarakat. Semoga kedepannya hasil ini dapat membantu Kepala Puskesmas Kubutambahan II serta pemegang kebijakan untuk meningkatkan dimensi yang dominan mempengaruhi kepuasan. Hasil ini walaupun tidak menemukan hubungan dengan variable tangible tetapi selanjutnya diharapkan ada alokasi dana untuk meningkatkan sarana prasaranadan tetap memperhatikan dimensi yang lainnya. Penelitian ini juga dapat menjadi sebuah acuan bagi penelitian selanjutnya dengan lebih detail menilai dimensi kepuasan dan dimensi dari kualitas pelayanan.

\section{DAFTAR PUSTAKA}

Al-Nehyadi, Hamda, S., Abdallah, S., \& Malik, M. (2018). Measuring patient's sa tisfaction of healthcare services in the UAE hospitals: Using SERVQUAL. International Journal of Healthcare Management, 11(2), 96-105.

Andriani, A. (2017). Hubungan Mutu Pelayanan Kesehatan Dengan Kepuasan Pasien Diruangan Poli Umum Puskesmas Bukittinggi. Jurnal Endurance, 2(1), 45. https://doi.org/10.22216/jen.v2i1.461

Fenny, A. P. okua., Enemark, U., Asante, F. A., \& Hansen, K. S. (2014). Patient satisfaction with primary health care - a comparison between the insured and noninsured under the National Health Insurance Policy in Ghana. Global Journal of Health Science, 6(4), 9-21. https://doi.org/10.5539/gjhs.v6n4p9 
Analisis Kualitas Pelayanan terhadap Kepuasan Masyarakat di Puskesmas Kubutambahan II Desa Tamblang Kecamatan Kubutambahan Kabupaten Buleleng Bali Tahun 2020

Luh Made Sri Lestari

Hasnih., Gunawan., H. (2016). Pengaruh Lima Dimensi Kualitas Pelayanan PublikTerhadap Tingkat Kepuasan Masyarakat di Kelurahan Ompo Kecamatan Lalabata Kabupaten Soppeng. Jurnal Mirai Management, 1(2), 426-445. Retrieved from https://id.scribd.com/document/413697237/koder

Kuntoro, W., \& Istiono, W. (2017). Kepuasan Pasien Terhadap Kualitas Pelayanan di Tempat Pendaftaran Pasien Rawat Jalan Puskesmas Kretek Bantul Yogyakarta. Jurnal Kesehatan Vokasional, 2(1), 140. https://doi.org/10.22146/jkesvo.30327

Meesala, A., \& Paul, J. (2018). Service quality, consumer satisfaction and loyalty in hospitals: Thinking for the future. Ournal of Retailing and Consumer Services, 4O, 261-269.
Pundenswari, P. (2017). Analisa Pengaruh Kualitas Pelayanan Publik bidang Kesehatan terhadap Kepuasan Masyarakat. Jurnal Publik, 11(1), 13-21. Retrieved from https://journal.uniga.ac.id/index. $\mathrm{php} / \mathrm{JPB} /$ article/view/2/2

Supartiningsih, S. (2017). Kualitas pelayanan kepuasan pasien rumah sakit: kasus pada pasien rawat jalan. Jurnal Medicoeticolegal Dan Manajemen Rumah Sakit, 6(1), 9-15.

Syaifulloh, M. D. (2011). Pengaruh Dimensi Kualitas Pelayanan Terhadap Kepuasan Pasien Poliklinik Paramedina Tlogosari Semarang. Semarang.

Tjiptono, F., \& Candra, G. (2005). Service, Quality and Satisfaction. Yogyakarta: Andi Yogyakarta. 